\title{
An Analysis of the urban development process in six major cities in Afghanistan from 1978-2018
}

\author{
Authors: Asadullah Hanif ${ }^{1}$; Jalil Ahmad Pouya ${ }^{2}$; Shafiqa Ahmadi ${ }^{3}$; Najibullah Loodin 4 \&* \\ 1 Research Center, Ghalib University; asadullah.ramin98@gmail.com \\ 2 Research Center, Ghalib University; jalilahmad.pouya@ghalib.edu.af \\ 3 Ferdowsi University of Mashhad; sh11ahmadi@gmail.com \\ 4 Research Center, Ghalib University; loodin2234@gmail.com \\ * Correspondence: loodin2234@gmail.com ; Tel.: 0093-798-697-629
}

\begin{abstract}
The rapid increase in population along with the economic activities led to rapid depletion of natural resources. Land use studies help us analyze the impacts of urban development on environment. Given the political upheavals in Afghanistan, this study aims to analyze how urban development evolved from 1978 to 2018 in six major cities- Kabul, Kandahar, Kunduz, Herat, Mazar-e Sharif and Jalalabad- in Afghanistan using Landsat Satellite Images. This study is based on quantitative approach. ArcGIS 9.4 software was used to synchronize the Landsat Satellite Images within the area of study. The results of the study show that the Annual rate of urban land expansion in Afghanistan was the lowest (average 1.07 square kilometers per year) during the military presence of Soviet Union in Afghanistan while it was the highest (3.35 square kilometers per year) from 2001 to 2018 due to the military presence of US-led NATO forces, relative security and rapid economic activities in Afghanistan. The authors believe that this study could be further explored if other inter-connected factors, e.g., the role of culture, literacy, immigration etc., are incorporated into the study of urban development processes in Afghanistan.
\end{abstract}

Keywords: Urban development; land use/ land cover; Soviet Union; major cities; Afghanistan

\section{Introduction}

Land cover changes and land use are essential for strategic planning for resource management and environmental changes [1]. Land cover changes are affected by various factors such as politics, nature, economy, population, etc. The increase in population along with economic activities are the two important factors that contributed to the conversion of agricultural lands, forests and pastures into urban lands [19]. That is why we feel that the study of land cover and land-use changes are important to be explored.

A number of scholars have analyzed land-use change/land cover trends using satellite imagery and remote sensing. For instance, Fazal has studied the trend of urban land development in Saharanpur, India from 1988 to 1998. He found out that the land built around the city has increased significantly [6]. Using satellite imagery, Lopez et al. examined the development of urban lands in Puerto Rico. The findings of the research show that the urban area has increased by $16.1 \%$ in the course of 1977 to 1994 [16]. Moreover, using temporal-spatial trends, it is argued that urban land increased by $71 \%$ in the course of ten years (1990-2000) in Beijing and Tianjin cities of China [30]. Additionally, the National Academy of Sciences has examined 326 cases of urban development using remote sensing. They concluded that during 1970-2000 almost 58,000 square kilometers of agriculture and forest lands had been converted to urban lands mainly in India, China, and Africa [21]. Similarly, the analysis land use/land cover changes in Rominger, Nainital and Uttarakhand, India show that the area of land built in the city of Rominger, India has increased by $8.88 \%$ whereas the green space, agricultural and irrigated lands have declined by $9.41 \%, 0.69 \%$ and $2.76 \%$ respectively from 
1990 to 2010. Hence, population growth is a driving force in expansion of urban lands in developing countries such as China $[10,34]$ and India $[21,28]$.

Despite the importance of the application of satellite images in assessing the land use and land cover changes studies, a very few studies focused on land use and land cover changes in urban settings in Afghanistan. For example, it is contended that the trend of urban development and its influential factors in Kabul city using existing land use maps, population data, economic data and Landsat satellite imagery from 1964 through 2008. Due to the rapid increase in population along with economic activities, the urban area in Kabul city had expanded fourteen-fold in 2008 compared to the 1964 's [1].

However, we feel that studying land cover and land use changes especially in Afghanistan is not comprehensive without inclusion of political factors. In the course of 1978 to 2018, the country has undergone a range of political changes leading to the expansion of urban development in Afghanistan or widespread migration from Afghanistan. That is why this research examines how political upheaval contributed to the urban development processes in six major cities- Kabul, Kandahar, Kunduz, Herat, Jalalabad and Mazar-e Sharif- in Afghanistan from 1978 [Soviet Union-backed government] to 2018 [US-backed government]. The paper will first explore the study area followed by the method section. Next, the findings of the research will be discussed. Finally, the paper will wrap up the discussion by presenting the conclusion section.

\section{Study area}

Afghanistan is a mountainous and landlocked country located in Central Asia. It lies between 29 $22^{\prime} 53^{\prime \prime}$ to 38 $29^{\prime} 27^{\prime \prime}$ north latitude and $60^{\circ} 28^{\prime} 41^{\prime \prime}$ to $47^{\circ} 51^{\prime} 47^{\prime \prime}$ east longitude. The area of the country is estimated to be more than 650,000 square kilometers. Afghanistan shares border with Iran, Pakistan, Turkmenistan, Tajikistan, Uzbekistan and China. The country is divided into thirty-four provinces of which Kabul is the capital and Herat, Kandahar, Balkh, (Kunduz) and Jalalabad are the major cities within the country [22].

The country has experienced a number of political events in the last 40 years; ranging from the fall of the monarchy and the establishment of the republic to the Cold War and the battle between anti-government groups and the government. Of course, these political events adversely affected the urbanization and economic conditions of the country.

\section{Political events in Afghanistan}

The most important political events that have taken place in Afghanistan in the last 40 years are as follows:

Coup (April 27th 1978): The coup ended the first Republic of Afghanistan under the leadership of Mohammad Daud Khan and paved the way for the Democratic People's Republic of Afghanistan. With the direct financial, political, military and strategic support of Soviet Union, the Democratic people's party has led the country for fourteen years. However, the political presence of Soviet Union in Afghanistan has caused uprising of the people against the government $[5,7,33]$. 
Revolution (April 27th, 1992): This revolution puts an end to the Democratic People's Republic of Afghanistan and the military presence of Soviet Union in Afghanistan. In fact, the revolutionists- Afghan Mujahedeen (mostly the common people) - took over the government and established Islamic Republic of Afghanistan. Due to political turmoil and lack of coordination among the leaders of revolutionists, Taliban took over and ruled the country for almost six years resulted in widespread migration of Afghans to the neighboring and western countries [30].

Bonn Conference, Interim Government (December 22nd, 2001): Following the 9/11 attack in the US, NATO forces overthrew the Taliban government and established an interim government for six months followed by transitional government of Afghanistan. During this period, the government was responsible to logistically facilitate presidential elections in Afghanistan. With the establishment of Islamic Republic of Afghanistan in 2004 and the relative security in the country, the immigrants returned to Afghanistan contributed to the economic development of the country through massive investments [4].

The aim of this research is to assess the trend of urban development in six major cities- Kabul; Kandahr; Kunduz; Mazar-e Sharif; Herat and Jalalabad cities (as shown in figure 1) in Afghanistan from 1978 to 2018.
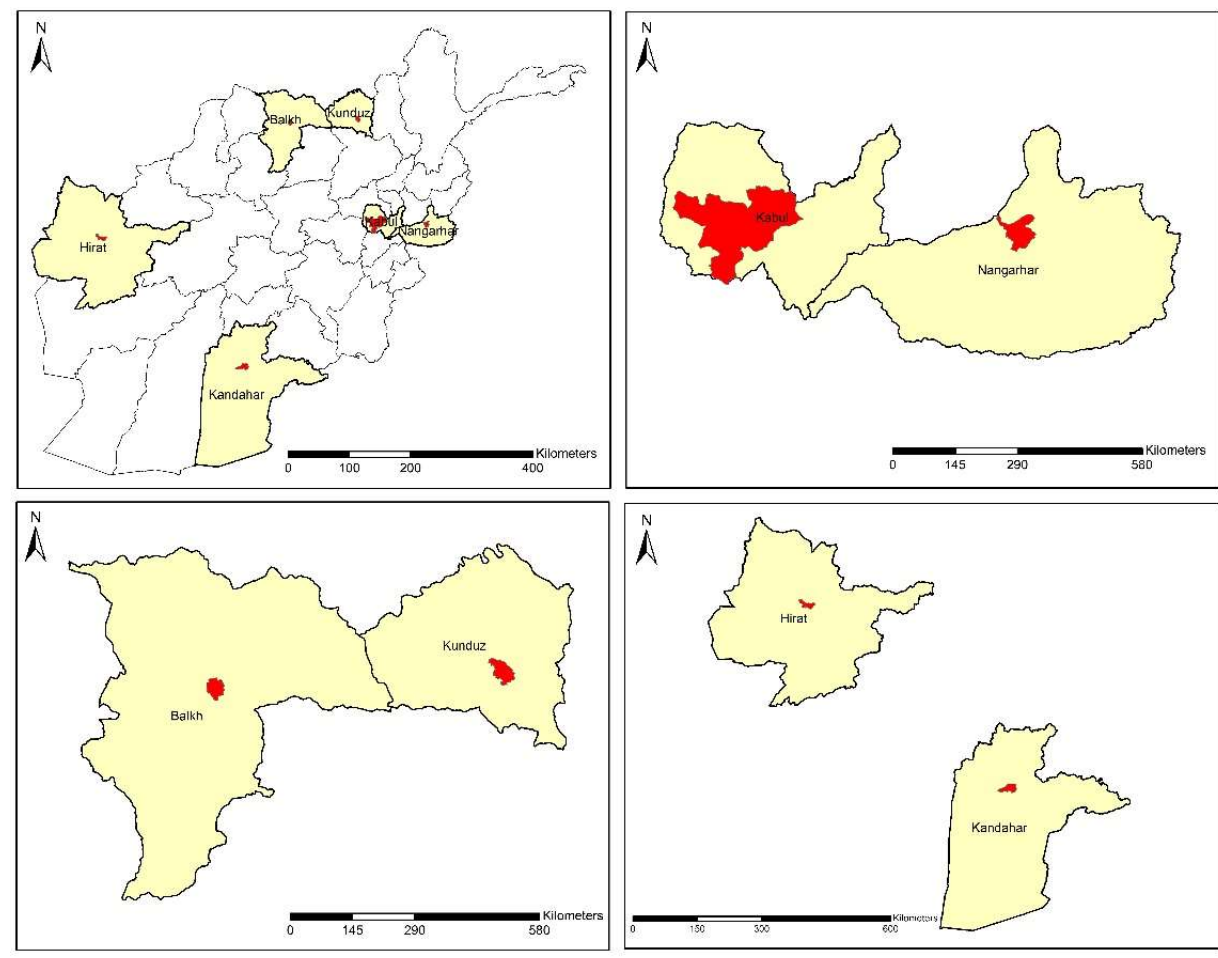

Figure (1): Study area 


\section{Research Methods}

\subsection{Collecting data}

To examine the urban development processes in six major cities in Afghanistan for the last forty years (1978-2018), images of Landsat 2, 5 and 8 satellites were freely downloaded from United States Geological Survey (USGS) website.

Table (1): List of Landsat satellite images

\begin{tabular}{|c|c|c|c|}
\hline Area & $\begin{array}{l}\text { Date of Acquisi- } \\
\text { tion }\end{array}$ & $\begin{array}{l}\text { Land SAT Se- } \\
\text { ries }\end{array}$ & Process \\
\hline Kabul & 1977-07-01 & MSS & $\begin{array}{l}\text { Atmospheric Correction } \\
\text { Maximum likelihood Classifi- } \\
\text { cation }\end{array}$ \\
\hline Kabul & 1992-07-07 & TM 5 & \\
\hline Kabul & 2001-08-01 & TM 5 & \\
\hline Kabul & 2018-07-15 & OLI 8 & \\
\hline Herat & 1977-07-06 & MSS & \\
\hline Herat & 1992-07-03 & TM 5 & \\
\hline Herat & 2001-07-12 & TM 5 & \\
\hline Herat & 2018-07-11 & OLI 8 & \\
\hline Kandahar & 1977-07-21 & MSS & \\
\hline Kandahar & 1992-07-07 & TM 5 & \\
\hline Kandahar & 2001-07-08 & TM 5 & \\
\hline Kandahar & 2018-07-06 & OLI 8 & \\
\hline Jalal Abad & 1977-07-18 & MSS & \\
\hline Jalal Abad & 1992-07-16 & TM 5 & \\
\hline Jalal Abad & 2001-07-09 & TM 5 & \\
\hline Jalal Abad & 2018-07-08 & OLI 8 & \\
\hline Mazar e Sharif & 1977-07-03 & MSS & \\
\hline Mazar e Sharif & 1992-07-14 & TM 5 & \\
\hline Mazar e Sharif & 2001-07-07 & TM 5 & \\
\hline Mazar e Sharif & 2018-07-06 & OLI 8 & \\
\hline Kunduz & 1977-07-20 & MSS & \\
\hline Kunduz & $1992-07-23$ & TM 5 & \\
\hline Kunduz & 2001-08-01 & TM 5 & \\
\hline Kunduz & 2018-07-15 & OLI 8 & \\
\hline
\end{tabular}

\subsection{Satellite image processing}

For pre-processing phase of the satellite imagery, radiance and QUAC atmospheric corrections were applied using ENVI 5.3 software program. 
For the processing phase, the Un-supervised classification method was applied. The five components of land uses (constructed lands, barren lands, agricultural lands, mountains and irrigated areas) were classified using the Maximum Likelihood algorithm. Then, ArcGIS 9.4 software was applied to synchronize the data obtained from the classification within the area of study. Moreover, the Kappa coefficient was used to obtain the classification accuracy, which can be seen in Table (2).

Table (2): Evaluation of satellite image classification accuracy

\begin{tabular}{rcccr}
\hline City/Year & \multicolumn{4}{c}{ Kappa coefficient } \\
\cline { 2 - 5 } & 2018 & 2001 & 1992 & $\mathbf{1 9 7 7}$ \\
\hline Kabul & 0.92 & 0.86 & 0.82 & 0.80 \\
\hline Herat & 0.94 & 0.84 & 0.82 & 0.82 \\
\hline Kandahar & 0.90 & 0.86 & 0.84 & 0.78 \\
\hline Jalal Abad & 0.88 & 0.82 & 0.80 & 0.76 \\
\hline Mazar e Sharif & 0.90 & 0.88 & 0.82 & 0.78 \\
\hline Kunduz & 0.92 & 0.88 & 0.80 & 0.82 \\
\hline
\end{tabular}

\subsection{Annual urban land growth rate}

To assess the trend of urban development in six major cities in Afghanistan, formulas $1 \& 2$ have been applied to calculate the Annual rate of urban land expansion ( $\mathrm{Km}^{2} /$ year), and the standardized annual growth rate (\%) of urban areas [28].

$A G R_{\text {area }}=\frac{A_{\text {end }}-A_{\text {start }}}{d} e$

$A G R_{\text {standard }}=\left[\left(\frac{A_{\text {end }}}{A_{\text {start }}}\right)^{1 / d}-1\right] \times 100 \%$

AGR= Annual rate of urban land expansion

Astart= the extent of the urban area at the initial time period

Aend $=$ the extent of the study at the final time period

$\mathrm{d}=$ the time span of the study in years [28] 


\section{Results}

Given the relative security along with the economic development in Afghanistan [12, 24], specifically in six major cities- Kabul, Herat, Kandahar, Jalalabad, Mazar-e-Sharif and Kunduz, the urban environment has grown by an average of ten times in the last forty year. For instance, the urban area within Kabul city has expanded from $73.6 \mathrm{~km}^{2}$ to $333.44 \mathrm{~km}^{2}$. Similarly, Herat, Kandahar, Jalalabad, Mazar-e Sharif and Kunduz cities have also been expanded from $6.21,7.37,4.72,4.6$ and $4.11 \mathrm{~km}^{2}$ to $68.07,91.70,49.32,65.04$ and $42.14 \mathrm{~km}^{2}$.

Table 3 and figure 2 show that the urban land growth of the six major cities in Afghanistan was slow and steady from 1979 through 1992. However, there was a slightly rapid urban expansion from 1992 to 2001 followed by a rapidly increased expansion from 2001-2018. For example, from 1992 through 2001 (in the course of nine years) the urban area of the major cities- Kabul, Herat, Kandahar, Jalalabad, Mazar-e Sharif and Kunduz- have expanded by 41.44\%; 93.0\%; $98.7 \% ; 89.3 \% ; 51.6 \% ; 73.7 \%$ respectively.

Table (3): Urban land development in 6 major cities of Afghanistan

\begin{tabular}{|c|c|c|c|c|c|c|c|c|}
\hline \multirow[b]{3}{*}{ City/Year } & \multicolumn{8}{|c|}{ Urban Land Growth } \\
\hline & \multicolumn{2}{|c|}{1977} & \multicolumn{2}{|c|}{1992} & \multicolumn{2}{|c|}{2001} & \multicolumn{2}{|c|}{2018} \\
\hline & $\begin{array}{l}\text { Increase of } \\
\text { Urban } \\
\text { Land }\left(\mathrm{Km}^{2}\right)\end{array}$ & $\begin{array}{l}\text { Increase of } \\
\text { Urban } \\
\text { Land (\%) }\end{array}$ & $\begin{array}{l}\text { Increase of } \\
\text { Urban } \\
\text { Land }\left(\mathrm{Km}^{2}\right)\end{array}$ & $\begin{array}{l}\text { Increase of } \\
\text { Urban } \\
\text { Land }(\%)\end{array}$ & $\begin{array}{l}\text { Increase of } \\
\text { Urban } \\
\text { Land }\left(\mathrm{Km}^{2}\right)\end{array}$ & $\begin{array}{l}\text { Increase of } \\
\text { Urban } \\
\text { Land (\%) }\end{array}$ & $\begin{array}{l}\text { Increase of } \\
\text { Urban Land } \\
\left(\mathrm{Km}^{2}\right)\end{array}$ & $\begin{array}{l}\text { Increase of } \\
\text { Urban Land } \\
(\%)\end{array}$ \\
\hline Kabul & & & 54.58 & 74.15 & 53.13 & 41.44 & 152.13 & 83.9 \\
\hline Herat & & & 8.89 & 143.1 & 14.05 & 93.0 & 38.92 & 133.5 \\
\hline Kandahar & & & 11.37 & 154.2 & 18.51 & 98.7 & 54.45 & 146.1 \\
\hline Jalal Abad & & & 6.09 & 129.0 & 9.66 & 89.3 & 28.85 & 140.9 \\
\hline Mazar e Sharif & & & 10.41 & 226.3 & 7.75 & 51.6 & 42.28 & 185.7 \\
\hline Kunduz & & & 5.36 & 230.4 & 6.98 & 73.7 & 25.69 & 156.1 \\
\hline
\end{tabular}




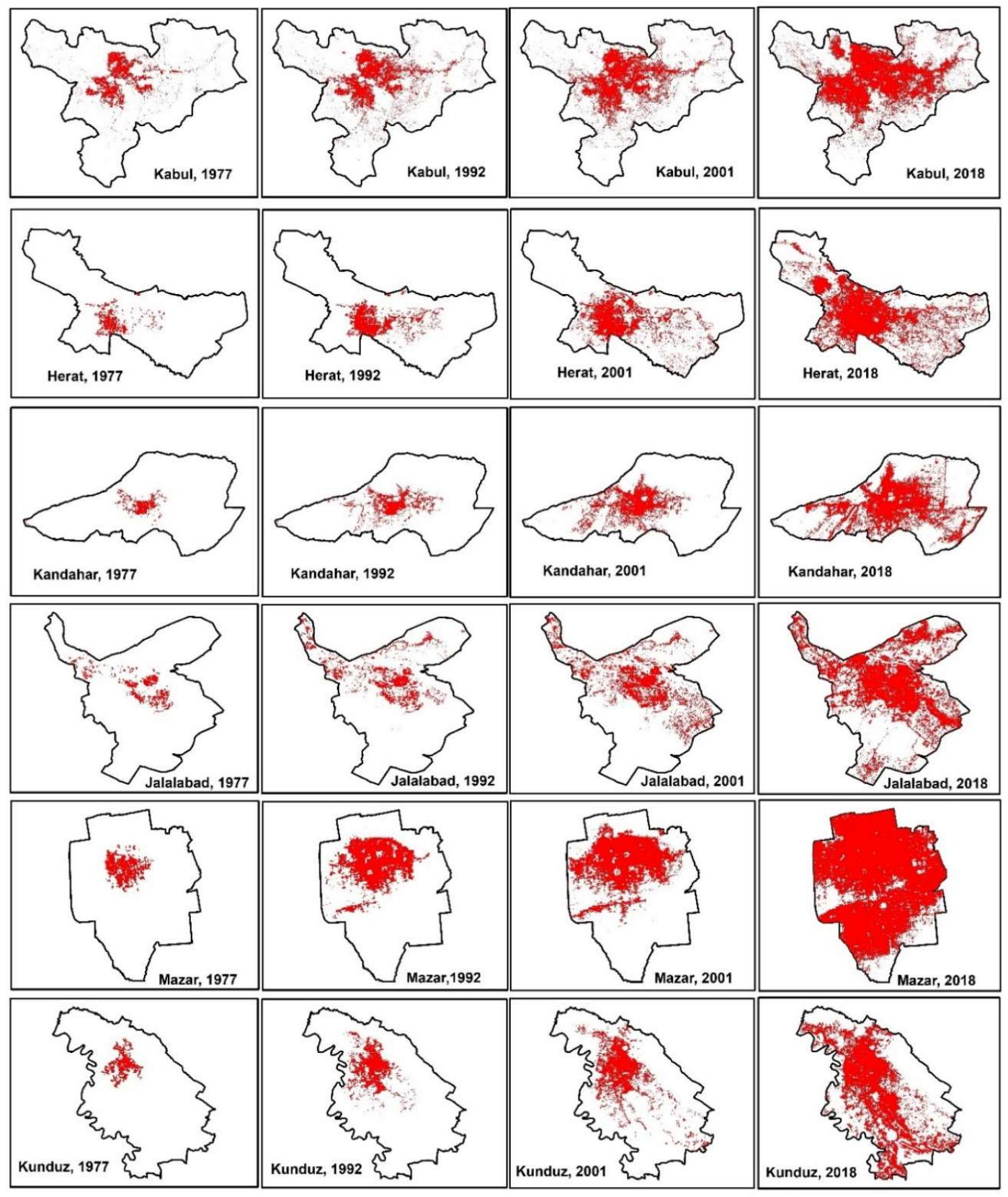

Fig 2: the process of urban development in major cities of Afghanistan (1977-2018) 
Additionally, table 4 shows the annual urban growth rate of the six major cities in Afghanistan. According to the table, during the presence of Soviet Union in Afghanistan, the annual urban expansion rate of Kabul, Herat, Kandahar, Jalalabad, Mazar-e Sharif and Kunduz was 3.63; 0.59; 0.76; 0.41; 0.69; and 0.36 square kilometers respectively; and the annual average urban growth rate can be estimated as 1.07 square kilometers.

Table 4: Average annual growth of urban areas in six major cities in Afghanistan

\begin{tabular}{|c|c|c|c|}
\hline \multirow{2}{*}{ City/Year } & $1977-1992$ & $1992-2001$ & $2001-2018$ \\
& $K^{2} / \mathrm{yr}$. & $K \mathrm{~m}^{2} / \mathrm{yr}$. & $\mathrm{Km}^{2} / \mathrm{yr}$. \\
\hline Kabul & 3.63 & 5.90 & 8.95 \\
\hline Herat & 0.59 & 1.56 & 2.29 \\
\hline Kandahar & 0.76 & 2.05 & 3.20 \\
\hline Jalal Abad & 0.41 & 1.07 & 1.67 \\
\hline Mazar e Sharif & 0.69 & 0.86 & 2.48 \\
\hline Kunduz & 0.36 & 0.76 & 1.51 \\
\hline Average & 1.07 & 2.03 & 3.35 \\
\hline
\end{tabular}

\section{Discussion}

Over the last four decades, Afghanistan experienced several historical and political upheavals. As the result of economic and political instability in Afghanistan, the Soviet Union-backed government has collapsed resulted in the rise of Mujahedeen government followed by Taliban Regime [27]. Taliban Regime, however, was overthrown by the US-led NATO forces after the 9/11 terrorist attack in New York City, the US [3]. The military presence of NATO forces in Afghanistan contributed to the betterment of socio-economic, political conditions of the country. That is why urban development has grown significantly in especially in the six major cities in Afghanistan.

Given the political and socio-economic conditions of Afghanistan, the paper will, now, further elaborate the trend of urban development in six major cities in Afghanistan.

\subsection{First period (1978-1992)}

After the coup of April 27th, 1978, Afghanistan was ruled by the Soviet Union-backed Democratic People's Party of Afghanistan. However, the military presence of Soviet Union in Afghanistan was strongly opposed by regional and international military powers such as Pakistan, Saudi Arabia and the USA [17]. It is argued that urban land is one of the main driving forces of environmental degradation around the world $[9,28]$. During fourteen years rule of Demo- 
cratic People's Party of Afghanistan, the shift from green areas to urban areas in Afghanistan was relatively steady. The paper has found out that the average urban growth rate in six major cities in Afghanistan was $1.08 \mathrm{~km}^{2} / \mathrm{year}$, among which Kabul city (the capital of Afghanistan) has experienced a high level of urbanism. For instance, the average growth of Kabul city is estimated at $3.63 \mathrm{~km}^{2} /$ year while the average urban growth rate during the presence of Soviet Union in five other major cities in Afghanistan is estimated at less than $1 \mathrm{~km}^{2} /$ year.

The reason why urban growth rate was relatively steady during 1978-1992 was the presence of Soviet Union and their confrontation with the 'Mujahedeen gorillas' that were financially and logistically supported by the United States, Pakistan and Saudi Arabia (Parenti, 2001). The military confrontation of US-backed anti-government group and the Soviet Union-backed government led to the widespread migration of Afghans to the neighboring countries and the destruction of the infrastructure sector in Afghanistan [11, 23].

\subsection{Second Period (1992-2001)}

The conflict between the Soviet Union-backed government and Mujahedeen finally ended in 1992 resulted in the victory of Mujahedeen. As the result of ethnic divisions, Mujahedeen failed to establish a powerful government that could represent all ethnic groups [4]. Such differences provided the opportunity for an Islamist group called Taliban to take over the government and establish the "Islamic Emirate of Afghanistan" in 1996 in Afghanistan. Similar to Mujahedeen's government, Taliban also failed to improve the livelihood of the Afghan people [4].

Our analysis shows that neither Mujahedeen nor Taliban had the opportunity to address unplanned urban development within the country. Despite having been a fragile state in Central Asia, the average urban growth rate from 1992-2001 was higher than the first period (1978-1992). For example, during the Mujahedeen and Taliban regimes, the average urban expansion rate of Kabul city was $5.9 \mathrm{~km}^{2} /$ year whereas it was $3.63 \mathrm{~km}^{2} /$ year in the second period. The authors believe that the main reason behind urban development in the second period is the return of immigrants from the neighboring countries, e.g., Iran and Pakistan. In the course of 1992 to 1995, almost 1.3 million refugees voluntarily returned to Afghanistan [11]. This unplanned urbanization resulted in the creation of socio-economic challenges [2] within major cities in Afghanistan.

\subsection{Third Period (2001-2018)}

The collapse of Taliban regime in Afghanistan in 2001, along with the establishment of US-backed government in Afghanistan significantly led to expansion of urbanism in Afghanistan [15, 20]. The urban area in Kabul city, for example, expanded by 3.05\% compared to the urban growth rate in Kabul city in the course of 1992-2001. The political and military presence of NATO forces, the financial support of US-led NATO forces to Afghan government, the massive return of the refugees, relative security and high economic developments are some of the reasons that largely contributed to the urbanism within Afghanistan. According to the reports, Afghanistan welcomed more than five million Afghan refugees from Iran and Pakistan [11]. 
Also, the military presence of US-led NATO forces along with the rapid economic growth in Afghanistan triggered Afghan rural communities to move to urban areas [29]. Of course, climate change- induced drought [13-14, 20] along with insecurity also forced farmers to migrate to nearby cities $[8,25]$. It is argued that more than one million Afghan people are in need of food and water in Herat city [32]. It signifies how climate changes [13] affected the livelihood of rural Afghans who were forced to settle in urban area in Afghanistan [18].

\section{Conclusion}

Afghanistan has been affected by various political and historical events. These changes have also impacted the urban development processes in Afghanistan. The paper has assessed the evolution of urbanism in three different time period from 1979 to 2018 in six major cities in Afghanistan. During the first period (1978-1992), the shift from green areas to urban areas was relatively low and steady. This is because Soviet Union-backed government was engaged in internal war with Mujahedeen who were logistically and financially supported by US and its allies. Afghanistan experienced a seemingly rapid urban expansion during Mujahedeen and Taliban regimes (1992-2001). However, this rapid urban expansion was structurally unplanned.

The paper also documented that the six major cities- Kabul, Kandahar, Kunduz, Mazar-e Sharif, Jalalabad and Herathave witnessed the highest urban development from 2001-2018. This is due to the massive return of the Afghan refugees from neighboring countries along with the rapid economic development and relative security conditions in Afghanistan. It is argued that the rapid unplanned urban development has significantly led to socio-economic challenges within major cities in Afghanistan. Finally, the authors believe that this research will help policy makers revisit the trends of urban development within the major cities in Afghanistan.

Conflicts of Interest: The authors declare no potential conflicts of interest for publishing the paper.

Authors' contribution: The authors equally contributed to the writing of the manuscript.

\section{References}

1. Ahmadi, A. , Kajita, Y. (2017). 'Evaluation of Urban Land Development Direction in Kabul City, Afghanistan'. World Academy of Science, Engineering and Technology, Open Science Index 122, International Journal of Urban and Civil Engineering, 11(2), 152 - 162.

2. Bapari, M. Y., Haque, M. E., Chowdhury, D. K., \& Islam, M. J. (2016). Impacts of Unplanned Urbanization on the Socio-Economic Conditions and Environment of Pubna Municipality, Bangladesh. Journal of Environment and Earth Science, 6(9), 105-114.

3. Bonilla, L. (n.d.). USA 19 Years On, Does a Post-9/11 Generation Remember the Attacks? Https://Www.Voanews.Com/Usa/19-Years-Does-Post-911-Generation-Remember-Attacks. Retrieved July 8, 2021, from https://www.voanews.com/usa/19-years-does-post-911-generation-remember-attacks

4. Collins, J. J. (2011). Understanding war in Afghanistan. National Defense University Press. 
5. Dogan, S. (2011). Turkey's Presence and Importance in Afghanistan. USAK Yearbook of International Politics and Law. https://www.academia.edu/1065605/Turkeys_Presence_and_Importance_in_Afghanistan.

6. Fazal, S. (2000). Urban expansion and loss of agricultural land - a GIS based study of Saharanpur City, India. Environment and Urbanization, 12(2), 133-149. https://doi.org/10.1177/095624780001200211

7. Ghubār Ghulām Muhammad, \& Fayez, S. A. (2001). Afghanistan in the course of history. All Prints Inc.

8. Glinski, S. (2021, June 2). Another drought looms. Is Afghanistan better prepared? The New Humanitarian. https://www.thenewhumanitarian.org/news-feature/2021/6/2/as-drought-looms-afghanistan-faces-another-mi gration-crisis.

9. Hahs AK, McDonnell MJ, McCarthy MA, Vesk PA, Corlett RT, et al. (2009) A global synthesis of plant extinction rates in urban areas. Ecology Letters 12: 1165-1173

10. Han, S. S. (2010). Urban expansion in contemporary China: What can we learn from a small town? Land Use Policy, 27(3), 780-787. https://doi.org/10.1016/j.landusepol.2009.10.010

11. International Organization of Migration (2014), Afghanistan: Migration Profile

12. Jalali, Ali A.. "The Future of Afghanistan." The US Army War College Quarterly: Parameters 36, 1 (2006). https://press.armywarcollege.edu/parameters/vol36/iss1/9

13. Loodin, N. Aral Sea: an environmental disaster in twentieth century in Central Asia. Model. Earth Syst. Environ. 6, 2495-2503 (2020). https://doi.org/10.1007/s40808-020-00837-3

14. Loodin, N., Keith, T., Arynova, A. et al. A critical analysis of the food-energy-water nexus in the Kootenai River Basin. Sustain. Water Resour. Manag. 7, 26 (2021). https://doi.org/10.1007/s40899-021-00508-w

15. Loodin, N., Warner, J. Hydro-hegemonic dynamics on the transboundary Harirud River Basin in a post-Talibanist Scenario. Water International (forthcoming).

16. López, E., Bocco, G., Mendoza, M., \& Duhau, E. (2001). Predicting land-cover and land-use change in the urban fringe. Landscape and Urban Planning, 55(4), 271-285. https://doi.org/10.1016/s0169-2046(01)00160-8

17. Middle East Institute, Washington DC. (2009, December 2). Afghanistan, 1979-2009: In the Grip of Conflict. https://www.mei.edu/sites/default/files/publications/2009.12.Afghanistan\%201979-2009.pdf

18. Mihran, R., (2011). Rural Community Vulnerability to Food Security Impacts of Climate Change in Afghanistan: Evidence from Balkh, Herat, and Nangarhar Provinces. UW Space. http://hdl.handle.net/10012/5965

19. Naab, F. Z., Dinye , D. R., \& Kasanga, K. R. (2013). Urbanization and its impact on agricultural lands in growing cities in developing countries: A case study of Tamale in Ghana. Academia.edu.

https://www.academia.edu/33590304/urbanisation_and_its_impact_on_agricultural_lands_in_growing_cities_ in_developing_countries_a_case_study_of_tamale_in_Ghana.

20. Nagheeby, M., Warner, J. The geopolitical overlay of the hydropolitics of the Harirud River Basin. Int Environ Agreements 18, 839-860 (2018). https://doi.org/10.1007/s10784-018-9418-9

21. National Academy of Sciences. 2001. Growing Populations, Changing Landscapes: Studies from India, China, and the United States. Washington, DC: The National Academies Press. https://doi.org/10.17226/10144

22. Palka, E. J. (2000, November 30). Afghanistan: A Regional Geography. ERIC. https://eric.ed.gov/?id=ED476014.

23. Parenti, C. (2001). America's Jihad: A History of Origins. Social Justice, 28(3 (85)), 31-38. Retrieved July 9, 2021, from http://www.jstor.org/stable/29768089

24. Qassem, A. S. (2016). Afghanistan's Political Stability: A Dream Unrealised (1st Edition). Taylor and Francis.

25. Qureshi, Asad Sarwar; Akhtar, Mujeeb. 2004. A survey of drought impacts and coping measures in Helmand and Kandahar provinces of Afghanistan. Colombo, Sri Lanka: International Water Management Institute (IWMI). 21p 
26. Rawat, J. S., Biswas, V., \& Kumar, M. (2013). Changes in land use/cover using geospatial techniques: A case study of Ramnagar town area, district Nainital, Uttarakhand, India. The Egyptian Journal of Remote Sensing and Space Science, 16(1), 111-117. https://doi.org/10.1016/j.ejrs.2013.04.002

27. Reuveny, R., \& Prakash, A. (1999). The Afghanistan war and the breakdown of the Soviet Union. Review of International Studies, 25(4), 693-708. doi:10.1017/S0260210599006932

28. Seto KC, Fragkias M, Güneralp B, Reilly MK (2011) A Meta-Analysis of Global Urban Land Expansion. PLoS ONE 6(8): e23777. https://doi.org/10.1371/journal.pone.0023777

29. Singh, A. K. (2013). Afghanistan: to 2015 and beyond,edited by Toby Dodge and Nicholas Redman. Asian Ethnicity, 14(4), 559-560. https://doi.org/10.1080/14631369.2013.803806

30. Tan, M., Li, X., Xie, H., \& Lu, C. (2005). Urban land expansion and arable land loss in China-a case study of Beijing-Tianjin-Hebei region. Land Use Policy, 22(3), 187-196. https://doi.org/10.1016/j.landusepol.2004.03.003

31. Tạin Zạhir. (2005). Afghānistān dar qarn-i bīstum: 1900-1996. Muhammad Ibrahīm Sharīatī Afghānistānī.

32. United Nations Food and Agriculture Organization. (2019, March 27). Communities affected by drought in Afghanistan are struggling with hunger. http://www.fao.org/emergencies/fao-in-action/stories/stories-detail/en/c/1187153/.

33. Wafadar, K. (1981). Afghanistan in 1980: The Struggle Continues. Asian Survey, 21(2), 172-180. doi:10.2307/2643762

34. Wu, Y., Zhang, X., \& Shen, L. (2011). The impact of urbanization policy on land use change: A scenario analysis. Cities, 28(2), 147-159. https://doi.org/10.1016/j.cities.2010.11.002 